\title{
Tax collection in the Roman Empire: a new institutional economics approach
}

\section{Óscar Gutiérrez ${ }^{1}\left[\right.$ Marco Martínez-Esteller $^{1}$}

Accepted: 4 December 2021 / Published online: 24 December 2021

(c) The Author(s) 2021

\begin{abstract}
This paper reviews the Roman tax collection system since the Late Republic to the Principality, focusing on the transition from the tax-farming system to a more centralized, census-based administration. We attempt to justify this transition according to New Institutional Economic theories (Transaction Cost Economics and Property Rights Theory). The paper argues that, during the Republic, the auction-based system of tax farming ended up giving place to opportunistic behaviors and abusing practices due to information asymmetries and contract incompleteness, enhanced by the collusion of tax farmers and governors. The Principality improved the efficiency of the tax collection system through the introduction of a bureaucratic and censusbased administration, which allowed imperial employees to monitor the tax-farming activities.
\end{abstract}

Keywords Roman Republic $\cdot$ Principality $\cdot$ Tax-farmers $\cdot$ New institutional economics $\cdot$ Moral hazard $\cdot$ Incomplete contracts

JEL Classification D23 $\cdot$ D73 $\cdot$ N23

\section{Introduction}

Besides the military importance and economic advantages of the Roman victories, the conquests entailed the administration of new territories in a vast empire, which in turn needed the creation of new institutions in order to deal with the problems

Óscar Gutiérrez

oscar.gutierrez@uab.es

1 Departament of Bussiness Economics, Edificio B, Universitat Autónoma de Barcelona, Campus de Bellaterra, Cerdanyola del Vallés, 08193 Barcelona, Spain 
derived from the territorial expansion. This paper analyzes the administration of tax collection in the Roman territories by means of the conceptual apparatus of New Institutional Economics ${ }^{1}$-NIE henceforth-, exploring the role that the novel institutions and arrangements played. In particular, we review the transition of the tax collection system from the Late Republic until the Principality, arguing that Transaction Cost Economics-TCE henceforth-and Property Rights Theory-PRT henceforth—can explain some of its features. ${ }^{2}$

The Roman conquests can be seen as investment opportunities whose returns derived from booties, slaves, mining, taxes et cetera. Consequently, a costly administration was needed to follow, manage, and collect the corresponding revenues. Analyses of the administration of the Roman Empire can be found in Hopkins (1980), Goldsmith (1984), Duncan-Jones (1998), Temin (2001, 2006), Arruñada (2016), Poitras and Geranio (2016) among others. The present paper focuses on the administration of tax collections. The relation between Roman conquests and tax collection went back and forth: taxes were necessary to finance the military campaigns, and the new territories became sources of new tax levies. We analyze the evolution of the Roman tax collection system, from the decentralized system of the Late Republic until the more structured and hierarchical one of the Principality, but the analysis may be generalized to other Roman institutions. We try to justify that efficiency arguments can aid to explain the evolution of the Roman institutions devoted to tax collection.

The analysis leads to two main conclusions. Firstly, the tax farming system used in the Republic worked acceptably well for a long time, at least from the Roman point of view. However, the system ended suffering from severe dysfunctions over time: information asymmetries and incomplete long-term contracts between taxfarmers and the Roman authority led to opportunistic behaviors by governors and tax farmers, often in collusion. Thus, the Senate was not able-or had no interest-in creating an adequate system of monitoring the tax farming activities in the provinces.

Secondly, we interpret the Augustus' reforms according to Williamson's TCE and Hart's PRT $^{3}$ suggesting that a more centralized administration helped to improve the previous system. In particular, we suggest that an imperial hierarchy intended to monitor the tax-farming activities and the creation of censuses helped mitigate the opportunistic attitudes and abuses in the provinces. The new administration was still rather decentralized, but more structured than the Republican one, with imperial agents supervising tax collection activities and governors depending hierarchically on the Emperor (who controlled the larger part of the provinces). We interpret these changes in terms of an efficient institutional choice, comparing the arguments offered with alternative, power-based explanations (McGuire \& Olson, 1996; Olson, 1993). The analysis can be useful in the current debate about which activities of the

\footnotetext{
${ }^{1}$ Built up by Williamson, Coase, Alchian, Demsetz, Ostrom, North, Barzel, Holmstrom, Milgrom, Hart and others.

2 Macher and Richman (2008) offer a revision of applications of TCE to social sciences.

3 See Williamson $(1975,1979,1985)$, Hart (1995).
} 
public sector are better to externalize to private contractors, and which ones to maintain under the state control.

The paper is structured as follows: Section 2 reviews the Roman history from the Late Roman Republic to the Principality. Section 3 is devoted to describe the tax collection system, interpreting it in terms of an efficiency search according to NIE theories. Section 4 discusses the results, deepening some analyses, and compares the NIE interpretation with power-based arguments. Section 5 summarizes and concludes the paper. An Appendix contains a brief review of the evolution of tax-collection during the considered period.

\section{Conquests and governance in Rome}

In this section we briefly review the historic period covered in the paper. The first subsection is devoted to the Late Roman Republic, a rather decentralized system of governance, and the second to the Principality, with a more centralized administration of the provinces. The review focuses on the Roman institutions devoted to the administration of the territories, and in particular to tax collection.

\subsection{The late republic}

In the study of the military history of Rome we can clearly differentiate two phases: the first one, from the foundation of Rome until the end of the Second Punic War in 201 BC. The second one, from 201 BC to the end of the Republican conquests in $50 \mathrm{BC},{ }^{4}$ and the succession of civil wars that followed it. The established division corresponds to the different ideas of warfare in each phase. In the period up until 201 BC Rome's reasons to go to battle were mainly geopolitical, with the intention to gain influence to get a share of the world's power. There was also an economic interest, since wars had proved to be very lucrative in terms of booty and slaves, but this was more of a secondary aim. However, from 201 BC onwards, warfare acquired a different meaning. Romans no longer saw it as a means to ensure supremacy over neighboring tribes, nor as a way to ensure its own survival against a powerful enemy. From then on, warfare would be considered a very lucrative way of doing business. Frank (1933) estimates that during the period from 200 to $157 \mathrm{BC}$ warfare accounted for more than $70 \%$ of the state's revenues. As a matter of fact, the income provided by conquests was so large that taxation on Roman citizens was abolished in $167 \mathrm{BC},{ }^{5}$ the expenses of the state primarily being supported by the provinces until the third century AD; see Hoffman (2017).

Once a territory was conquered, Romans approved a fundamental law establishing the particular rules of the province. In fact, a territory, even when pacified and occupied, was not considered to be a province until it had its own law. These laws

\footnotetext{
${ }^{4}$ Year of the Gaul's conquest by Julius Caesar (1985).

${ }^{5}$ See Coats and Pecquet (2013, p. 521).
} 
attended to the particularities of the land, dividing its property, establishing the taxes, recognizing rights to local tribes and states and indicating the applicable legal order. If these fundamental laws could validate an existing set of laws, structures, administrations, taxes, et cetera, they usually did. Romans intended to innovate and interfere as less as possible, always respecting the already established structures of governance as long as they were effective and willing to cooperate under Roman directorship. Consequently, there were usually little similarities between the different administrations among the provinces, as they all respected the previous principles and structures that had been there for decades or centuries before the Romans arrived. Also, local inhabitants still held the available positions of such administrations, being the submission to the Roman governors the only thing in common. Thus, a great deal of the management that was still in charge of organizing the provinces was not integrated into the Roman administration, neither in its political institutions. However, the highest level of management was fully Roman. Every year elections were held, and a set of magistrates was chosen by the people of Rome. The Senate then decided who, among those magistrates that held the position of consul or praetor, was sent to manage each province and secure the interests of Rome in the territory. They would then become the Roman governors. ${ }^{6}$ These governors were agents of Rome in the provinces they had to manage. They were both the military chiefs and the civil governors of those territories, and so they were able to command armies, but also to establish taxes and administer justice. All in all, the power that governors had over the provinces they were entrusted with was virtually absolute, and they tended to make use of it. In addition, the Senate did not pay the local administration (nor the governors or any other kind of magistrate) a salary, which raised some questions on the motivations of the Roman governors to seek those positions (the local administrations had their own salaries or benefits).

Let's briefly explain the functions of governors in order to understand their role in tax collection. Originally, nothing else but securing the order, the peace, and the Rule of Roman Law. Roman governors had very little administrative staff and a force of combat that was often symbolic (except if conflict was expected, in which case full legions were deployed). They basically oversaw the matters of the province, making sure that taxes were collected, the peace was respected, the justice administered, and revenues delivered to the Senate. And, once their term had come to an end, governors were supposed to simply return to Rome, abandoning all their power. Thus, the Roman idea about the role of governors consisted of thinking a way to secure a set of conditions to allow the province to reach the maximum economic growth and profitability. This would benefit Rome through taxation, as well as the Roman citizens who had been investing in business opportunities all over the area. However, reality largely differed from this theoretical idea. They were as kings (or viceroys) in their kingdom, and most of them also acted like that. In fact, governors enjoyed a high degree of autonomy since the Roman Senate had very little power to check their counterparts in the provinces or the rules they decided to establish. This autonomy, together with the need to earn income by themselves, made the

\footnotetext{
${ }^{6}$ See Richardson (1994, Sect. 3.1).
} 
relationship between governors and Rome similar to a modern franchise: Rome gave governors a part of its power in exchange for peace, order and Roman rule, sharing with them the property rights over the province's wealth.

It must be noted that governors were not what we would call today "public servants". They were not integrated within the structure or the hierarchy of the Roman administration because they were elected following the democratic procedures determined by law. And, although the Senate chose who to send to manage each province-with those governors being expected to inform periodically and to ask for permission in a large variety of matters before taking any action-reality was that governors could frequently "free-ride". The free-riding behavior involved actions such as plundering the province independently or together with the tax collectors (see below), or engaging in military conflict with neighboring tribes and states normally without prior provocation in a personal quest for fame and self-enrichment. ${ }^{7}$ To make things worse, governors started to raise private armies by the end of the Republic (Coats \& Pecquet, 2013), which only worsened the situation as tensions between the Senate and the governors became rather usual. In addition, direct control by the Senate was poorly articulated due to political plots and schemes, and there was also a constant and open conflict among senators. ${ }^{8}$ Consequently, by the last century BC, governors' free-riding attitudes and "agency problems" became such a major source of trouble that they supposed a clear menace to the system stability. Of course, there were always magistrates that fully respected their mandates, functions and obligations, but they are to be considered the exception rather than the norm. ${ }^{9}$

This is in summary the breeding ground for the governors' free-riding management of the provinces, and the rather ineffective actions that were taken by the Senate in order to put an end to it. Why did this happen? In first place, there were no adequate incentives for Roman governors to act accordingly to the Senate's mandates. Actually, the only way for them to receive something in return for their service was to act selfishly, to free-ride and to take the Republic's or the province's rents [which they did, acting like directors cheating in their franchises, which frequently ended in collusion with tax-farmers; see Jones (1968, p. 11)]. Secondly, a major flaw of the system was the inefficacy of the existing controls. Not only was the Senate giving absolute power to unprepared individuals that had simply won an easily bribable election procedure, ${ }^{10}$ but also sent them far away from the Senate's influence and provided them with armies. This would translate, in the best scenarios, into disastrous managements that impoverished the provinces and reduced Rome's income; and, in the worst ones, into rogue governors that had their own armies (not

\footnotetext{
7 In fact, Caesar's conquest of the Gaul is a perfect example of a free-riding governor that acted against the Senate's orders.

${ }^{8}$ It has to be pointed out that the Senate was composed by two parties, the optimates and the populars, which by the last century of the Republic engaged in a never-ending fight for power that involved several civil wars until Augustus finally assumed the power in $27 \mathrm{BC}$.

9 Such is the case of Cicero, whose writings during his mandate gives us an idea of what a compliant consul usually did with his time in the province; see Frazel (2004).

10 Bribery was not only easy to perform, but also an accepted strategy to win votes (Lintott 1990).
} 
symbolic when a conflict was expected), which could threaten the stability of the Republic (Coats and Pequet, 2013).

In conclusion, the system implemented in the conquered provinces allowed Rome to administer quickly and quite efficiently a vast territory. ${ }^{11}$ Over time, however, the free-rider behavior of governors and the abuses often in collusion with tax-farmers made the system fail. It was so partially because the system trusted the management of Roman assets to a non-prepared, glory and wealth-seeking elite that usually took advantage of the absence or inefficacy of supervision to act opportunistically. The constant conflict among all parties, who openly fought each other in several civil wars during the last century of the Republic, together with the struggling of a Republican order that could no longer maintain its territories nor its magistrates and generals in line, hastened the Republic's downfall.

\subsection{The principiate}

In the year $27 \mathrm{BC}$, Augustus became the Emperor of the Roman domains, after almost a century of internal fights among the Roman political factions (the optimates and populars we have briefly explained in footnote 9). The advent of the principality entailed some important consequences. First, the Senate lost its power as the main ruler of Rome, starting a parallel institution order that would run the Roman Empire for the coming centuries. The Senate was still somewhat powerful, but limited to the formal control of a decreasing number of provinces and affairs; the Emperor, despite his absolute power, still respected the Senate formal power and the aura of tradition that surrounded the Republican institution (Kunkel, 1952). Second, the discretion of the province governors and other authorities was severely cut. During the Republic, the Senate enjoyed the property rights over the "assets" derived from the conquests. Over time, the differing interests among senators, as well as the franchised Roman power given to governors, resulted in a division of the property rights on the Roman assets, usually exploited by free-riding governors, senators and generals.

Nonetheless, once the institution of the Emperor was introduced there was a significant change in the balance of power of the Republic, and the Princep accumulated the property rights of most of the Roman wealth. In particular, the tax collection system was progressively re-organized (see Sect. 3.1 and the Appendix). The power that Augustus received was essentially absolute, meaning that he (and his successors) had the power to rule over almost everything in the Republican order. We are particularly interested in the power the Emperor had over the provinces and the Empire's administration. Many reforms were introduced to the foundational elements of the Roman provincial regime. The most relevant one was the distinction that divided existing provinces into two separated types: the senatorial provinces and the imperial ones, both of them with huge differences in terms of organization and management. The senatorial provinces were still controlled and managed by the

\footnotetext{
11 The Roman administration in the Republic was particularly efficient if compared with other empires (for example, taking into account the number of civil employees per citizen; see Hopkins (1980), Kiser and Kane (2007)).
} 
Senate according to the procedures explained in Sect. 2.1, while the imperial provinces were to be managed by the Emperor. Of course, due to the large number of imperial provinces, ${ }^{12}$ the Emperor could not rule them all by himself, so he created a brand new administration, directly under his control and independent from the senatorial one. Regarding the division criteria, provinces were classified according to their military and strategic interests. Thus, if a province was completely pacified and had no use for the Emperor, it was then given to the Senate for its management and enjoyment. In contrast, if the province was still being pacified, or if any kind of interest (not necessarily military) remained, then it was put under the Emperor's rule.

Since they are of particular relevance to our analysis, we shall review the Emperor's fiscal competencies. The state's resources as well as its sources of revenue were divided following the same principles that had been applied to the rest of the powers. Consequently, if during the Republic only one public treasury had existed, the Republic's aerarium, which integrated all the revenue received by the state, a second one was created to both collect the imperial sources of income ${ }^{13}$ and to provide funds to the rising imperial administration: the Emperor's fiscus. The fiscus, although dedicated to provide funds for the imperial administration and services, in addition to pay for the Emperor's personal expenses, it was legally the Emperor's personal and sole property, i.e., the personal patrimony of the Emperor, not an imperial treasury per se. Aside from the hereditary issues that arose from this situation, the fiscus as the Emperor's personal property also meant that the Emperor accumulated the largest part of the Roman state's revenue (this point becomes relevant in Sect. 3.2). We must remark that a large number of agents were employed in the management of the fiscus. In fact, there was even a public agent, the advocati fisci, who represented the claims of the fiscus in judicial proceedings, which shows us how many similarities existed between the Emperor's fiscal regime and nowadays systems (Brunt, 1966).

The new administration was decentralized, as no direct management was really possible because of the lack of fast communication and means of travel, but it was now more structured and better organized than the republican one. Imperial governors still held great power, ${ }^{14}$ but they were appointed and removed by the Emperor, thereby establishing a more hierarchical relation. The imperial administration, however, included much more than just the province direction performed by the imperial governors and their staff. This is how farming out of provincial taxes' collection, which had been another major source of abuses, corruption and plundering, also

\footnotetext{
12 They were, originally, larger in number than the provinces received by the Senate (12 vs. 10). In addition, the number continued to increase in the coming centuries enlarging the gap between them.

13 Among others, the Emperor's fiscus received its revenue from the taxes that were collected in the imperial provinces, the land controlled or owned by the Emperor that was rented, or the amounts paid for the enjoyment of public goods.

14 Although, not as much as under the Republic. For example, imposing new taxes required the sanction of the Senate or the Emperor (Brunt, 1966).
} 
became reformed by both the local administrations and the imperial agents (Bowman \& Rathbone, 1992). ${ }^{15}$

As discussed in Sect. 2.1, the main problem regarding province tax collection was the lack of means to perform it. During the Republic the operations were "outsourced", probably since the Romans had not developed any kind of census or land registry in the provinces. So, the simplest solution consisted of bidding the exploitation rights to private contractors by means of periodical auctions, who offered a stable amount of revenue in return, but the tax-farming system ended being unfair and corrupt; see Sect. 3.1. Facing a situation of abuses and corruption, Julius Caesar and later his successor Augustus carried out a set of notorious reforms to make tax collection fairer, which involved the progressive creation of censuses and registries by imperial agents all over the Empire. ${ }^{16}$ The creation of censuses made tax collection more easily supervised. The tax collection was performed according to the shared power between the imperial (or the senatorial) institutions and the local administrations. Thus, local administrations were responsible for collecting the taxes due in their own areas. The specific arrangements varied across provinces, but imperial agents monitored the tax collection activities across the empire and sent a part of the levies to either the aerarium or the fiscus.

\section{Tax collection $^{17}$}

\subsection{Two systems of tax collection}

In the beginning of the Roman expansion, although provincial governors had the power to establish taxes in the conquered territories, the levy collections were not managed by Roman authorities -neither by public servants on their behalf- but "outsourced" to private contractors within the power that public contracts provided them; see Hopkins (1980). These private contractors were known as publicani, whose origins date back to the early fourth century $\mathrm{BC}^{18}$; they also carried out other public tasks, like road building, and the exploitation of some local resources, such as mining. An important advantage of the tax-farming system was to know and collect in advance the funds from taxes, which allowed Rome to better plan future activities.

The publicani were organized through firms known as societatis publicanorum, which acquired their tax collection contracts through public auctions. They submitted their collection plans, each with a binding sum of taxes that were to be collected

\footnotetext{
15 The publicani continued to exist and were still able to bid for some public contracts, but they definitely lost a great deal of their previous power.

16 Who not only created the imperial provinces' censuses, but also the ones in senatorial provinces, which constitutes an example of the personal agents of the Emperor meddling with the senatorial management.

17 For the sake of completeness, the Appendix contains a brief review of the tax-collection system during the period covered in the paper.

18 See Badian, (1972, p. 16).
} 
during a certain period of time, ${ }^{19}$ and the contract went to the societas publicanorum which had offered the largest sum; see Appendix. The system may resemble the periodical competitive bids used by many automobile manufacturers in the selection of external suppliers. In overall terms and for many years, this solution worked well, taking into account that the development of a fiscal administration in all provinces would have required a substantial sunk cost expenditure of uncertain long-term amortization, something certainly difficult to pose for a rather decentralized republic. Probably for this reason, the implemented solution consisted of delegating the tax collections to private contractors linked to Rome by means of public long-term contracts, which gave a stable income to the State, secured no matter the circumstantial conditions of the land. Furthermore, for Rome, the publicani could be more trustable than the governors (Badian, 1972).

However, the absence of an effective supervision performed by either the Senate or the governors (who were probably more interested in ensuring larger revenues than in solving the problems of non-Roman inhabitants) led to the publicans to take advantage of their advantageous position to maximize to the limit the collections and consequently their profits. Thus, the system proved to be economically advantageous for Rome but excessively burdensome for the provinces, causing massive impoverishment and dissatisfaction among the local population. ${ }^{20}$ The root of the problem seems to be that the Roman state had not developed a census or any other kind of registry that made an orderly collection of the taxes possible (Neesen, 1981); this probably was the reason to initially externalize the tax collection to tax-farmers (for an explanation on the difficulties of creating censuses, see Hin (2013)). An additional problem was that governors, who were supposed to oversee the publicani in their operations, often ended up as their plundering accomplices or deliberately overlooking the publicans' activities, as Cicero described. ${ }^{21}$ Furthermore, it must be pointed out that governors benefitted most from the publicans' activity, because they had the power to use the province income during their term, deciding, also, how much was to be sent to the Senate. In this case, the problem could be the lack of enforcement of the public contracts, which led to a flawed organizational design where those who benefitted from the system did not bear the costs. Thus, the decentralization, the absence of censuses, and the negligent attitude of governors (when no collusion with tax-farmers) made possible a tax-farming system was often performed arbitrary and unfairly; see Jones (1968), Levi (1989), Richardson (1994).

In order to solve all those malfunctions, Augustus redesigned the fiscal administration [although Caesar had previously introduced some changes during the

\footnotetext{
${ }^{19}$ If the final collection was larger than the binding sum, the difference was taken as profits. If it was shorter they lost the difference. Of course, publicans were not usually short in their collections (rather the opposite).

${ }^{20}$ The laws for tax collection only established guidelines for its implementation, so that the Roman authority (the corresponding magistrate) had the power to modify the tax-farming contracts; thus, the publicani could be favored by the magistrates (who, usually, limited to follow previous practices). The magistrates also arbitrated in quarrels derived from tax collection activities.

${ }^{21}$ It is the illustrative case of Cicero against G. Verres, governor of Sicily; see Pritchard (1971), Richardson (1994, p. 588), Frazel (2004), McLeister (2016, Ch. 3e).
} 
Republic; see McLeister (2016, Ch. 1)]. Augustus introduced censuses in the provinces, and created a more centralized and hierarchical structure with a new class of loyal bureaucrats and civil employees who had to oversee the activities of the societates publicanorum. The reforms were implemented progressive and heterogeneously across the Roman territories, so that procuratores (imperial agents), publicans and local elites coexisted and both carried out tax collection activities during the Principate, while the republican system to some extent continued to exist; see Appendix. Although in most territories tax-farming activities continued being entrusted to the publicans, the establishment of a hierarchical and census-based organization of imperial supervisors helped reduce the information asymmetries between governors (local authorities) and Rome (central authority), diminishing the abusive way in which publicans carried out the tax-farming activities, often in collusion with governors. Contrary to tax-farmers, the new bureaucrats difficultly could take advantage of the information asymmetry, due to their personal bond with the Emperor, the existence of career concerns within the imperial bureaucracy, and the fact that their salaries did not depend on collections. Thus, the supervision over taxfarming activities lessened the information asymmetry (moral hazard) and thus the opportunistic and abusive behaviors.

Moreover, the new administration restructured the tax system. First, the system became more homogenous across (imperial) provinces; in particular, many tax benefits enjoyed by some cities were suppressed. Second, new indirect taxes were created (the centessima rerum venalium, the vecessima hereditatis; see "Appendix"). At the same time, the creation of an imperial bureaucracy and the employment of censuses allowed Rome to use a different kind of contracts with tax-farmers in the collection of the new indirect taxes: instead of the contracts that forced the tax-farmers to pay the state a lump-sum amount in advance (the corresponding amount to the auction winner), the tax-farmers paid a percentage of the taxes levied, something impossible to carry out without the supervision of impartial employees. The system based on percentages allowed the state to increase the tax collection since the (monitored) tax-farmers tried to maximize their revenues. And, as pointed out by McLeister (2016, p. 124), transferring the collection of taxes to imperial employees would not have performed so well, because they lacked incentives to maximize profits (and then state revenues). On the other hand, if the publicani had collected taxes on a percentage basis without supervision of imperial agents, abuses would have arisen again.

All these reforms entailed an efficiency improvement in tax collection activities since Augustus was able to get higher collections while bringing peace to the Roman territories. The collections were higher but more predictable, the system was fairer and more homogeneous across the empire, and the abuses of governors and publicani ended or drastically diminished. This improvement took place at the expense of tax farmers, corrupted governors and local elites, whose earnings tended to diminish (in some cases the tax-farmers could not necessarily worsen, because of the percentage system mentioned above). It can be argued that Augustus could close a virtuous circle with his reforms: a higher tax burden would allow him to strengthen the military, which in turn would help him to bring peace to the provinces. With the reversion of the republican chaos, the welfare of the provincial citizens improved, even 
if that implied bearing higher taxes. This allowed the new system to be fairer and better designed, thus enhancing economic growth and consequently higher collections, which in turn yielded increased revenues to pay the military and the imperial administration employed in the supervision of tax collection activities. So, according to our point of view, an efficiency improvement was achieved.

\subsection{The evolution of Roman tax collection under NIE perspectives}

In this subsection we interpret the evolution of the Roman tax collection system towards a more centralized system according to NIE theories, in particular Williamson's TCE and Hart's PRT. ${ }^{22}$ It must be remarked that Williamson's TCE and Hart's PRT share some assumptions and features, converging in many of their predictions, but not completely. Whinston (2003) analyzes the coincidences and differences in detail, pointing out the diverging conclusions that the theories can yield.

Appealing to Williamson's TCE, the reforms of the tax collection system can be explained in terms of maladaptation of long-term contracts, which allow severe expost implementation problems. In our context, it would be due to the incompleteness of the contracts of tax collection activities derived from the (rapidly developed) institutional design, which gave tax-farmers an advantageous position favored by the information asymmetries and the lack of an effective supervision. The role played by provincial governors in the administration of tax collection (see Sect. 2.1) is crucial to understand the problem. First, in spite of being Roman agents, governors often disregarded their supervising functions, even colluding with tax-farmers. Second, the role of governors across the Empire was set by law, so the Senate did not have much flexibility in the provinces' administration. Hence, the institutional framework left too much room to opportunistic behaviors due to the contractual incompleteness that derived from the existing laws and rules. (This contrasts with a modern firm, which can solve organizational problems in a more straightforward manner; for example, the Senate did not enjoy the flexibility to bargain separately with private contractors due to institutional constraints). In order to overcome the problems associated to tax collection activities, a possible solution entailed their management by the central authority. This solution did not necessarily imply replacing tax-farmers with civil employees but instead could entail exerting a tighter control over taxfarmers based on trustable information provided by censuses. The substitution of a decentralized tax-farming system by a bureaucratic census-based administration with civil employees (either in charge of monitoring tax-farmers or replacing them) is well explained in TCE terms: "Moving from less to more complex governance entails introducing added security features, reducing incentive intensity, and incurring added bureaucratic costs" (Williamson, 2000, p. 603). The supervision of taxfarming activities by imperial employees assisted by censuses allowed the Roman authority to reduce the information asymmetry and thus the hazards associated to

\footnotetext{
${ }^{22}$ Langlois (1995) analyzes the advantages of centralizing the resources allocation following Coase's (1937) pioneer work. Coase theorem (1960) cannot be invoked in this context as the transaction costs associated to tax collection transactions were not negligible.
} 
institutional incompleteness which, jointly with the specificity of the investments required for tax collection, was the root of the problem (see Sect. 4.2).

The relation between the Emperor and the new class of public bureaucrats was based on their loyalty: they were not the opportunistic magistrates that the Republic had seen, but probe employees that had been selected directly by Augustus; and probity is the fourth factor that, according to Williamson, favors the internalization of activities. ${ }^{23}$ The establishment of a more formal, hierarchy-based organization made up of skilled and loyal employees helped reduce the sources of opportunism associated to the republican tax collection system, something resembling a situation of hold-up due to contract incompleteness enhanced by information asymmetries (see Sect. 4.2). A weakness of Williamson's approach is the implicit assumption that opportunism problems due to contract incompleteness are avoided by integrating the transactions within the firm (where opportunism disappears), which in turn makes probity particularly relevant. The next interpretation of Augustus' reforms appeals to Hart's version of the PRT and circumvents such limitation.

The Late Republic, by giving almost absolute power to governors, was in some sense dividing the property rights on the Roman assets among different owners who had different objectives. Although the Senate was formally the single owner of the empire assets and sources of income, the power was too dispersed and it did not work as such (so that the Senate was incapable of maximizing the value of those assets and cash-flows through the decentralized system). Augustus attempted to reverse such a situation by shifting to more centralized institutions. In an economic sense, the Emperor became the one who actually accumulated the property rights of (most part of) the Empire and, in order to administrate the collection of taxes across the territory, he created censuses in the provinces and set up a costly bureaucracy to monitor tax-farming activities. Let us justify this reform in terms of Hart's PRT. We recall that, as expressed by the PRT, the owner who eventually accumulates the property rights is that who assigns them the maximum value. And according to Hart's version of the PRT (1995), in a context of incomplete contracts, specific investments and high quasi-rents, this maximization can be favored through investments in human capital, as the owner of the property rights already possessed the greater part of the non-human assets.

Many of the problems that arose from tax-farming activities were possible because the provincial governors did not properly supervise the tax-farming activities, thus allowing for opportunism, corruption and abuses. However, an effective supervision of tax-farmers by governors was difficult to perform given the existing information asymmetries that favored the publicans. An adequate supervision of the publicans' activities made necessary the creation of censuses, which represents an investment in non-human capital. Obviously, the censuses should be managed by the Roman authorities; otherwise, the pre-existing information asymmetries would have increased. Once the (specific) investment associated to creating censuses was made, an investment in human capital to ensure their complete use became highly

\footnotetext{
23 The other three are: (i) asset specificity; (ii) high frequency of the transactions; and (iii) environmental complexity and the existence of information asymmetries.
} 
advisable. This was so that the information provided by the censuses and the human capital (know-how) became complementary assets, in the sense that the expected quasi-rents (cash-flows) from the investments in human capital could increase with those in non-human capital — the investment in publicans' human capital was inadvisable for Rome as it could enhance moral hazard. Thus, the new administration of tax collection also entailed the investment in human capital, in this case consisting in the selection and training of the imperial employees. Thus, as a direct result of the decision-making power over provinces and the sources of income located within them, Augustus invested in censuses and human capital to optimize the tax collection. His skilled and loyal personal employees would eventually become the imperial administration, the first one in Roman history, in charge of managing and engaging with the administration of the Empire. This new class of bureaucrats and public servants was later employed all over the Empire, not only in positions devoted to tax collection. For example, imperial employees also administered the finances of the Empire and providing services in both the provinces and the City of Rome.

\section{Discussion}

In the previous section, we have tried to justify the administration of Roman tax collection in terms of economic efficiency. In particular, we argue that NIE arguments help explain the tax-farming system carried out by the publicani during the Republic, and its evolution towards a more centralized system in the Principate. In this section we discuss and deepen the arguments provided, and compare them with power-based explanations.

\subsection{Efficiency in tax collection}

In overall terms and for many decades, the decentralized tax-farming solution managed by the publicani worked well, and allowed Rome to avoid the sunk cost associated to developing a fiscal administration in the provinces, a specific investment of rather uncertain results in a decentralized state. The implemented solution consisted of outsourcing the tax collection to private contractors with a periodically renewable auction system, which gave a stable income to the Republic. However, without an effective supervision performed by either the Senate or the governors, the system allowed the publicans to take advantage of the existing information asymmetries, which led to opportunistic behaviors and abuses in many provinces. Furthermore, the long-term contracts between tax-farmers and Roman state were rather incomplete (with unforeseen contingencies), which sharpened the problem given the inaction (if not collusion) of governors. Augustus reformed the tax collection system and progressively introduced a bureaucratic, more hierarchical, and census-based administration with loyal and skilled employees dedicated to monitor the tax-farming activities, in a kind of ancient Weberian bureaucracy. Thus, many of the problems that arose due to the lack of control and plain ignorance of what happened in the provinces during the senatorial management did not reoccur in the 
imperial administration, or not so gravely as in the Republic. First, the alignment of interests of governors with the Roman authority was no longer an issue: imperial governors were directly appointed and rewarded by the Emperor, who encouraged well-management and punished misconduct, a troublesome lack of the Republican regime. Second, the creation of censuses and the supervision of tax-farming activities by imperial agents diminished the opportunistic attitudes of governors and publicans. Obviously, moral hazard can also arise in organizations, but career concerns help reduce such a problem, and the imperial organization favored the appearance of career concerns (in contrast with the situation of the province governors in the Republic, whose positions were almost always a one-time job never to be repeated).

All in all, the approach taken by Augustus proved to be more adequate for the ruling of the tax collection in the Empire. However, the system was not so different from what it previously was. There still were a large number of provinces, whose circumstances remained unchanged, and governors who were chosen to manage such provinces for a period of time with a great deal of power that could be autonomously exercised. The modifications introduced changed the way governors were appointed (they were chosen directly by the Emperor) as well as some of their old competencies, such as raising taxes or engaging in military conflict. The way in which directions and communications were to be performed was also changed: the governors now had to answer before the Emperor. By means of these reforms, which turned the previously decentralized system into a more centralized and hierarchical one, the outcome of the management changed drastically. The abuses and opportunistic behavior of tax-farmers and governors, which often led to riots and revolts, ceased to be a major concern. The imperial administration was so superior compared to the senatorial one, that the first eventually encompassed the latter and absorbed all its competencies. The aerarium and the fiscus were separated entities at first, but over time the fiscus - that originally was meant to allude to the Emperor's treasury-was commonly used as a synonym to aerarium, the original word for public treasure; see Brunt (1966).

To conclude this subsection, let us suggest an explanation to why a superior outcome could be reached by the Emperor over the Senate, even though both institutions could have been considered a sole property rights owner. ${ }^{24}$ The Senate did not represent a unified organism, but it required consensus to decide; see Jankowski (2021) and Kiser and Kane (2007). And consensus, as happens with current cooperatives, entails high organization costs, ${ }^{25}$ which can be drastically reduced in a firm-like organization: a single entrepreneur can often adopt innovations that a committee could or would not because of the higher decision costs of the last one. In particular, the efforts required to reaching a consensus in a certain matter and to maintain it over a period of time are not cost-free. This line of reasoning can resemble Buchanan and Tullock (1962), or Alchian and Demsetz (1972), who justify the

\footnotetext{
${ }^{24}$ In a different context, Jankowski (2021) analyzes why the Republic's Constitution failed, suggesting that the Senate lacked the incentives to solve the problems that arose with the territorial expansion.

25 Due to, among other things, high coordination costs due to non-hierarchical decision-making, and high motivational costs due to free-riding attitudes.
} 
higher efficiency attained by capitalist forms of firms over the work cooperatives. The collegiate institutions undergo important organization costs in the decisionmaking process, and those costs are larger when the decision to be taken is: (i) more definitive than others (its consequences last more or even is perpetual); (ii) more complex than others (it involves more contingencies, which implies unpredictable consequences, due to randomness, lack of the required expertise, or the existence of informational asymmetries). When the Senate had to decide on how to manage the conquered territories, the taken decision was kept as simple as possible, and the already existing structures and institutions were good candidates despite not being appropriated, because its members perceived reaching lasting consensus as more costly. ${ }^{26}$ The decision-making process resembles why in modern large companies the property rights are separated from the management team, committed to maximize their value: because a more centralized procedure of decision-making is cheaper than consensual or collegiate procedures. Finally, we must recall that the reforms of the tax collection system introduced by Augustus must not be interpreted in the sense that dictatorships are economically more efficient than democratic systems, but only as the introduction of a more hierarchical architecture for the tax collection administration. In the next section we compare the Augustus' reforms to a car manufacturer that decides to shift outsourcing by in-house production.

\subsection{Contract incompleteness and hold-up}

Under some circumstances, it is optimal for the parties to sign a long-term contract, especially when there are specific investments involved. ${ }^{27}$ However, long-term contracts are rarely complete in the sense of exhausting all the possible future contingencies. Furthermore, environment uncertainty and the existence of information asymmetries enhance the likelihood of contract incompleteness. If non-contemplated contingencies occur, the contract becomes incomplete and one party may behave opportunistically until the contract expires. This situation is known as hold-up, which represents a central concept in Williamson's TCE and Hart's PRT. ${ }^{28}$ In order to avoid (actual or possible) hold-ups, the two contracting parties have the option to change the allocation of property rights over the specific investments involved (for example, by integrating the two firms). In our context, the contract for the management of tax collection activities in a province lasted five years and was rather incomplete. Tax-farmers and governors could thus take advantage of their positions, giving place to situations that, to some extent, can resemble the modern hold-up. This situation was worsened by the existence of the information asymmetries associated

\footnotetext{
${ }^{26}$ It could be argued that lasting consensus is simply unreachable due to the property structure of some companies or, in the case of the Senate, due to the short mandate duration of all its magistrates.

27 Investments are specific when they only yield the expected returns within the particular use it was intended; outside this operation, their value is much smaller (zero, or nearly zero) which makes them rather useless and limits the possibilities of the owner to re-direct the investment to other business opportunities. Typical sources of specificity are location, design and human capital.

28 See Klein et al. (1978).
} 
to the expertise of the publican, and the fact that the Senate lacked trustworthy information from the provinces.

According to our analysis, the change of the status quo carried out by Augustus in the Early Empire can be compared to the situation where an automobile manufacturer changes an external supplier (outsourcing) through in-house production (insourcing), like General Motors (GM) did in the thirties of the last century when Fisher-Body (FB) was integrated as a GM division. ${ }^{29}$ The integration of FB into GM drastically reduced the high transaction costs associated to a long-term contract that worked well at first but turned out to be excessively costly for one of the parties involved (GM) as the demand sharply increased. In the end, GM escaped from a hold-up situation that lasted several years by integrating FB into the organization. Similarly, ${ }^{30}$ the decentralized system implemented by the Senate in the provinces proved to be useful during decades, but corruption and opportunistic behaviors led to abusive conditions for the citizens, which ended complicating the decentralized tax-farming solution from the Roman point of view. The centralization reforms that Augustus carried out helped avoid this situation.

\subsection{Alternative interpretations}

In this subsection we suggest two additional interpretations of the tax collection problems in the Republic based on alternative NIE arguments. In both interpretations the problem arises from the fact that tax collection was part of a multidimensional objective. ${ }^{31}$ In a fairly general setup, Hart et al. (1997) develop a theory of government ownership under incomplete contracting, which the authors apply to prison privatization. ${ }^{32}$ The theory justifies the intervention of the government in a public good provision in order to keep the quality of the service high. Similarly, Augustus, after observing the "low quality" of the service (in particular, the unsatisfactory treatment received by the province communities and the risks associated to it), decided to complement the tax-farming system with a census-assisted

\footnotetext{
${ }^{29}$ For a review of the American automobile industry, see Langlois and Robertson (1989).

${ }^{30}$ The parallelism is not complete. First, tax-farmers were not integrated in the administration, being monitored by the imperial employees. Second, in the case of GM and FB there was a contract between two parties, while in our context there were two rules among three parties (if not four): the Roman state, the tax-farmers (not properly monitored by the provincial governors, and often in collusion with them), and the citizens.

31 Kiser and Kane (2007) appeal to a sociological version of agency theory to analyze the evolution of the Roman tax collection system, suggesting that its performance depended on the form of the state. In particular, the fact that the Roman Senate was a multiple principal plays a key role. Our approach shares some features with Kiser and Kane, but diverges from them in the analysis of the agency problem, and highlights the problems derived from "institutional incompleteness", which led to adopt a more centralized, hierarchical system. Furthermore, our approach does not require that senators had an economic interest in tax collection activities (which was forbidden by law; see Appendix).

32 The theory takes into account the cost and quality of service under alternative provision modes, a private provider and the government. According to the theory, the problems of contractual incompleteness make the case for in-house provision by the government straightforward, since getting the right level of quality out of a private contractor might be very expensive. We thank an anonymous referee for calling our attention on this reference and suggesting us the subsequent analysis.
} 
bureaucracy of imperial employees who could supervise the tax-farming activities. Thus, a fairer tax system reduced the likelihood of citizen riots provoked by the abusive behavior of tax-farmers allowed by governors. The new system seemed to be less open to corruption, so it could be perceived as fairer by the tax-payers, in line with Augustus' idea about the importance of moral behavior.

A similar argument may be sketched if the problem is analyzed as a situation of multitasking under moral hazard faced by governors [see Holmstrom and Milgrom (1991)]: when an agent has been assigned more than one unobservable task, the design of incentives is especially thorny, and it may become advisable to soften the monetary incentives. In the case at hand, governors had to administrate the provinces according to Rome's interest, which entailed a multidimensional objective involving fiscal and political aims. The change from a system in which one of the governors' activities entailed a strong compensation linked to tax collections -the supervision of publicans- to a system with a fixed salary could entail a drastic reduction of misconducts.

\subsection{Power-based explanations and the stationary-bandit argument}

So far, we have explained the reforms introduced by Augustus in the administration of tax collections by appealing to economic efficiency. This does not mean that, in general, centralizing the decision process necessarily leads to an efficiency improvement (and even less that dictatorships are economically more efficient than democratic or decentralized systems). The arguments provided are rooted in the NIE tradition and applied to a particular context, and in contrast with power-based explanations, consider that the institutional choices to some extent led to second-best efficiency. Accordingly, even though power issues refuse to go away-see Williamson (1999, p. 611) - the bargaining power of the contracting parties does not univocally explain the resulting equilibrium. This contrasts with Olson's stationary-bandit argument, where the stronger party is the lead beneficiary of the economic relationship. We also must remark that NIE arguments and power-based ones are not necessarily substitute explanations, but can be complementary. In fact, Olson's argument is interpretable in NIE terms as the peaceful order provided by the dictator enhances efficiency and the territory productivity. In Olson's words: "These claims have an echo in some literature in the "transactions costs" tradition that attempts to explain the emergence of various kinds of governments partly or wholly through voluntary contracts and the costs of the transactions associated with them"; see Olson (1993, pp. 568-569) and the references he cites. ${ }^{33}$

Olson (1993) and other authors justify the appearance of a dictatorial government as a "stationary-bandit", someone who uses its power -and in particular tax collection- to appropriate as much wealth as possible, including the income and assets of the territory. In exchange, the dictator provides the territory with some basic public

\footnotetext{
${ }^{33}$ In spite of some possible parallelisms and similarities, Olson disagrees with the NIE argument: "This literature is most constructive and interesting, but to the extent to which it tries to explain government in terms of voluntary transactions, it is not convincing"; see Olson (1993, p. 575, note 4).
} 
goods, for example a peaceful order and security against other bandits. According to Olson's argument, the population may prefer the existence of the stationary-bandit -and the corresponding predictable and relatively peaceful situation- to occasional roving bandits. The stationary-bandit argument has been successfully applied to political science. In particular, McGuire and Olson (1996) use economic reasoning to analyze collective decision processes in democracies and oligarchies. They demonstrate that autocrats with coercive power and an encompassing interest in their domain have an incentive to exercise the power partially or wholly consistent with the interests of society, so that "an invisible hand gives a roving bandit an incentive to make himself a public-good-providing king" (McGuire and Olson (op. cit., p. 73)). They also show that an optimizing majority that controls a society necessarily redistributes less income to itself than what a self-interested autocrat would do. ${ }^{34}$ Thus, the reforms introduced by Augustus may be explained through the stationary-bandit argument: Augustus set higher taxes, and this allowed him to expand and strengthen the military, which in turn helped him to bring peace to the provinces. In order to avoid the moral hazard problem associated to a stronger army, he limited the power of his generals. ${ }^{35}$ The suppression (or limitation) of the republican chaos improved the welfare of the provincial citizens, who could prefer paying higher taxes in a fairer and quieter situation. The shift in balance of authority and residual claimant rights turn performed by Augustus changed some policies; in particular, taxes could be to increased, which fits Olson's argument.

According to our view, the stationary bandit argument does not fully explain Augustus' reforms, which can be rather justified in terms of an efficient institutional choice. First, the stationary-bandit interpretation implies that the Senate would play the role of the roving bandits, which makes no sense since the Senate represented the state, and it did not "departure" from the territory, which is what roving bandits do. In fact, Augustus did not replace the existing roving bandits (the Senate) by a stationary bandit (himself), but reformed the existing Roman institutions -the senatorial ones- by changing laws and rules. Second, a number of complex measures were introduced to improve the collections, making the system fairer and better: the creation of censuses and a civil bureaucracy helped reduce the previous misconducts, abuses, opportunism and corruption originated by information asymmetries and institutional incompleteness; also, the establishment of new rules for splitting the collection of indirect taxes could be an adequate incentive to maximize both the state and the tax-farmers revenues, by means of a sharing rule similar to current franchises.

\footnotetext{
34 A more general analysis of the advantages and disadvantages of autocratic systems versus non-autocratic ones in terms of social welfare (taxes, public goods) is out of the scope of this paper; detailed analyses of the question can be found, among others, in Wittman (1989), Buchanan (1990), Olson (1991, 1993), McGuire and Olson (1996), Barzel (2000), Congleton (2001), Azfar and McGuire (2002), Overland et al. (2005), Gandhi and Przeworski (2006), Acemoglu and Robinson (2006), Egorov and Sonin (2011), Libman et al. (2012), Murphy (2019) and references therein.

35 Augustus expanded the military to 26 legions, with no general commanding more than two legions; see Jankowski (2021, ft. 8).
} 


\section{Summary and conclusions}

This paper reviews the managing of the Roman tax collection since the Late Republic to the Early Principality, justifying the arrangements used from a New Institutional Economics perspective. Following Williamson, we carry out the analysis in comparative institutional terms, trying to justify that efficiency arguments complement (if not prevail over) power-based explanations. The identification of an efficient institutional choice must be based on the comparison of costs associated to plausible alternatives. In our context, this entails comparing the organization costs associated to the administration implemented by Augustus to the transaction costs associated with the republican system. With the centralizing reforms performed by Augustus, the transaction costs associated to the republican tax collection drastically diminished. If our arguments are correct, the organization costs associated with the imperial system-including the creation of censuses and the implementation of a bureaucratic administration-were lower than the reduction of the enormous transaction costs of the corrupted republican system, because the census-based monitoring of tax-farmers and the introduction of better arrangements limited the opportunism due to information asymmetries and institutional incompleteness.

The main conclusions of the paper are the following. In the Republic, the tax collection activities were "outsourced", working well from the Roman point of view. Eventually the Republic was not prepared to rule such a vast domain and all the choices taken were forced to fit within the limitations of the institutional framework, which gave place to the emergence of abuses and opportunistic behaviors by governors and tax-farmers. These misconducting behaviors caused, or accelerated, changes in the tax collection administration. This could happen since the Senate lacked incentives to correct the emerging flaws, as pointed out by Kiser and Kane (2007) and Jankowski (2021). Thus, collegiate institutions (such as the Senate) had aggregate costs that made them less adequate in the decisionmaking processes associated to administrating a vast empire, which implied a disadvantage against more centralized, firm-like institutions.

During the Principality, in contrast, the tax collection administration and other institutions were (at least partial and progressively) substituted by a more centralized administration. This administration could resemble a Weberian bureaucracy, and in many aspects it would be similar to a modern firm with a well-defined hierarchy, a coordination that relied on the director's authority, and an incentives system encouraged by a system of salaries, promotion and rewards. We have argued that the reform of the tax system can be seen as the accumulation of the property rights on the assets of the Empire in Augustus, who had a better position and capabilities to maximize their value. This reassignment of property rights (a kind of "vertical integration") allowed Augustus to solve many of the ex-post implementation conflicts that arose from the incomplete contracts between the Roman authority and the tax-farmers. For such a purpose, he was able to create a ruling class including trustable bureaucrats, public servants and professional governors with career concerns. All in all, the management of tax collection activities in the 
Roman provinces improved in many aspects, reducing the negligence and opportunism that the Republican institutions had faced.

\section{Appendix: A brief review of tax collection}

In this Appendix we briefly review the evolution of the Roman system of tax collection; for detailed analyses, see Brunt (1966, 1990), Badian (1972), Hopkins (1980), Richardson (1994, Sect. 4), Temin (2006), McLeister (2016) and references along the text. Recall that taxation on Roman citizens (in particular the tributum) was abolished in $167 \mathrm{BC}$, remaining either abolished or at very low rates until the third century AD.

Before the Roman expansion, taxes were levied on all forms of property, with the purpose of paying the army in periods of war. The tax rates were modest, $0.01 \%$, sometimes up to $0.03 \%$, and taxes were levied on individuals, who were counted at periodic censuses; see Bartlett (1994, p. 290). As Rome expanded, the collected taxes increased, giving the Republic a much larger tax base through its provincial residents, which made unnecessary to levy a tax against Roman citizens. Sometimes, the taxes levied with military purposes were got back to the Roman citizens. In the provinces, the main form of tax was a tithe levied on entire communities, a kind of tax particularly easy to administer. Roman citizens stopped paying taxes in 167 B.C., with some exceptions during the Late Roman Republic. The Roman authorities of the local communities (magistrates, governors), had autonomy to decide how to divide the tax burden among the inhabitants. According to Frank (1933), tax collections amounted up to $22 \%$ of the Roman revenue from 200 to $157 \mathrm{BC}$.

In the vast territory under Roman domain, a class of private contractors called publicani was often utilized to collect provincial taxes. They were in charge of different types of tax collection, including direct taxes (in particular the tributum, a tax levied on property of Roman citizens) and indirect taxes (vectigalia, in particular portoria); they were also developed public tasks (like road building) and the exploitation of the natural resources (like mining); see Badian (1972). The publicans were Roman citizens, not senators (forbidden by law), frequently organized through jointstock companies known as societates publicanorum [a kind of partnerships of socii led by the manceps, and subordinated to the magister societatis in Rome; see Badian (1972), McLeister (2016), Poitras and Geranio (2016)]. They were very popular in Roman times, to the point that their relevance can be appreciated in the Bible; see Walker (1978). However, it must be noted that tax-farming activities carried out by private agents already existed before the Roman Empire; see Brunt (1990, p. 355). For the tax collection practices there were not homogeneous rules, but depended on taxes and territories. In the Early Republic some taxes (e.g., the tributum before its abolition) were collected by state officials; (Badian, 1972, p. 23). In tribes, the collection of the tributa was neither carried out by tax-farmers nor by state officials, but by wealthy citizens of the tribe (tribuni aerarii); Brunt (1990, p. 354). The direct tax levied in Spain (stipendium) was paid directly to the governor; (McLeister, 2016, p. 68). 
The usual manner to organize the tax collection activities was the following. The right to collect taxes in a particular province was auctioned, and the winner had to pay in advance for the right for the tax collection, which usually was a very lucrative business. Thus, tax-farmers loaned money to the state in advance of tax collections, often collected in-kind, and Rome was required to pay interest back to them. Tax farmers had to convert provincial taxes into cash, thus alleviating the Roman treasury from that burden. The tax collections must (expectedly) exceed the investment make by tax farmers: cash paid in advance to the state, plus the costs associated to run the business, plus the opportunity cost of the funds (this including the risk associated to collecting less than the original bid). Thus Rome delegated the task of tax collection, whose management was put under auction every few years, and carried out by the publicani. Periodically, usually every five years, these rights were bid. The completion system among societates of publicani offered the Roman authority (the Senate) a lucrative system that proved to work very well for many decades, both for the Roman treasury and for the tax-farmers. Over time, the system became abusive and corrupt: once an auction was won, the tax-farmers enjoyed an exaggerated discretion to perform the tax collection activities. As explained by Jones (1968, p. 11), the system got corrupted due to the collusion between governors and tax farmers, which allowed them to put a great tax burden on the local communities. This was possible due to the Roman authority, the Senate, being located far away and poorly communicated, making it difficult to exert any control. Moreover, the publicani lent cash at exorbitant rates, which led to a huge debt borne within the communities. Also, they could agree with farmers to speculate by buying and storing grain and waiting until times of shortage.

This troublesome situation led Augustus to set up a census-based tax collection system, which appears to have progressively replaced the tax-farming one (Temin, 2006, footnote 11), or at least coexisted with it (with the imperial employees supervising the tax-farmers' activities); according to Brunt (1990), there is no evidence that tax-farming activities were suppressed in the Empire. The more widespread opinion among academics is that tax-farming continued at least in some provinces, in which private tax-farmers and procuratores (state officials) cooperated; while in others, the lucrative business of tax farming, carried out autonomously of a central authority, did not last long much, and the publicani continued as money lenders and entrepreneurs. The evolution of the tax collection system also depended on the type of province (imperial provinces vs. senator ones), and on the type of tax (direct taxes vs. indirect ones). For example, the fiscal system in Roman Egypt is also generally considered to be different from the usual one in other provinces (Rathbone, 1993); and the collection of imperial indirect taxes in the Early Principate continued being farmed by the publican, as in the Republic (Rathbone, 1996), but in a different way (see below). There is not a precise knowledge on the date of the establishment of administrative boards to control the publicani, nor the way in which the procuratores substituted the private tax-farmers, or cooperated with them; see Günther (2018). The taxes on the provinces now paid a wealth tax (about 1\%) and a flat poll (tributum capitis) on each adult, which required regular censuses in order to count the taxable population and assess taxable property. It also led to a major shift in the basis of taxation. Under the tax-farming system, taxation was largely based on current 
income, which represented the main base of taxation (as the publicani bid against the income potential of the communities, a large fraction of the income increases became appropriated by them). Furthermore, some indirect taxes were also created (e.g., the centessima rerum venalium, something similar to a $1 \%$ VAT, and the vecessima hereditatis, something similar to a $5 \%$ inheritance tax). For the collection of the new (indirect) taxes, tax-farmers paid a percentage of the taxes levied, instead of paying the state a lump-sum amount in advance, the amount corresponding to the auction winner. The new system was only necessary for the collection of the created indirect taxes (due to the absence of previous records on which base the bids), but it seems that it ended being implemented for the collection of all indirect taxes; see McLeister (2016, p. 249).

With the centralized system, in addition to the Republic's aerarium, which integrated all the revenue received by the state, a second one was created to both collect the imperial sources of income and provide funds to the rising imperial administration: the Emperor's fiscus. Among others, the Emperor's fiscus received its revenue from the taxes that were collected in the imperial provinces, the rented land controlled or owned by the Emperor, and the amounts paid for the enjoyment of public goods; see Brunt (1966). The imperial system of flat levies instituted by Augustus based on wealth and population regularized the yield of the tax system, and greatly reduced its "progressivity"; this helped the local communities keep the wealth increases (instead of being shared with Rome), which enhanced economic activity (Bartlett, 1994, p. 292).

Acknowledgement The authors gratefully acknowledge R. Congleton (editor) and two anonymous referees for the insightful critics and suggestions made on the manuscript. They also thank Vicente Salas for the discussions and comments on earlier versions of the paper.

Funding Open Access Funding provided by Universitat Autonoma de Barcelona.

Open Access This article is licensed under a Creative Commons Attribution 4.0 International License, which permits use, sharing, adaptation, distribution and reproduction in any medium or format, as long as you give appropriate credit to the original author(s) and the source, provide a link to the Creative Commons licence, and indicate if changes were made. The images or other third party material in this article are included in the article's Creative Commons licence, unless indicated otherwise in a credit line to the material. If material is not included in the article's Creative Commons licence and your intended use is not permitted by statutory regulation or exceeds the permitted use, you will need to obtain permission directly from the copyright holder. To view a copy of this licence, visit http://creativecommons.org/licen ses/by/4.0/.

\section{References}

Acemoglu, D., \& Robinson, J. A. (2006). Economic origins of dictatorship and democracy. Cambridge University Press.

Alchian, A. A., \& Demsetz, H. (1972). Production, information costs, and economic organization. American Economic Review, 62(5), 777-795.

Arruñada, B. (2016). How Rome enabled impersonal markets. Explorations in Economic History, 61, 68-84.

Azfar, O., \& McGuire, M. (2002). The natural economic advantage of dictatorship over democracy: A “Gresham's Law" of governance. International Tax and Public Finance, 9(4), 451-463. 
Badian, E. (1972). Publicans and sinners: Private enterprise in the service of the Roman Republic. Cornell University Press.

Bartlett, B. (1994). How excessive government killed ancient Rome. Cato Journal, 14(2), 287-303.

Barzel, Y. (2000). Property rights and the evolution of the state. Economics of Governance, 1(1), $25-51$.

Bowman, A. K., \& Rathbone, D. (1992). Cities and administration in Roman Egypt. The Journal of Roman Studies, 82, 107-127.

Brunt, P. A. (1966). The "Fiscus" and its development. The Journal of Roman Studies, 56, 75-91.

Brunt, P. A. (1990). Publicans in the Principate. In P. A. Brunt (Ed.), Roman imperial themes (pp. 354432). Clarendon Press.

Buchanan, J. M. (1990). The domain of constitutional economics. Constitutional Political Economy, 1(1), $1-18$.

Buchanan, J. M., \& Tullock, G. (1962). The calculus of consent. The University of Michigan Press.

Caesar, C. J. (1985). De Bello Gallico. De Bello Civili. SARPE.

Coase, R. H. (1937). The nature of the firm. Economica, 4(16), 386-405.

Coase, R. H. (1960). The problem of social cost. Journal of Law \& Economics, 3, 1-44.

Coats, R. M., \& Pecquet, G. (2013). The calculus of conquests: the decline and fall of the returns to Roman expansion. The Independent Review, 17(4), 517-540.

Congleton, R. D. (2001). On the durability of king and council: The continuum between dictatorship and democracy. Constitutional Political Economy, 12(3), 193-215.

Duncan-Jones, R. (1998). Money and government in the Roman Empire. Cambridge University Press.

Egorov, G., \& Sonin, K. (2011). Dictators and their viziers: Endogenizing the loyalty-competence tradeoff. Journal of the European Economic Association, 9(5), 903-930.

Frank, T. (1933). Rome and Italy of the Republic, An economic survey of Ancient Rome (Vol. 1). John Hopkins University Press.

Frazel, T. D. (2004). The composition and circulation of Cicero's In Verrem. The Classical Quarterly, 54(1), 128-142.

Gandhi, J., \& Przeworski, A. (2006). Cooperation, cooptation, and rebellion under dictatorships. Economics \& Politics, 18(1), 1-26.

Goldsmith, R. W. (1984). An estimate of the size and structure of the national product of the Early Roman Empire. Review of Income and Wealth, 30(4), 263-288.

Günther, S. (2018). Taxation in the Greco-Roman world: The Roman principate. Oxford University Press. https://doi.org/10.1093/oxfordhb/9780199935390.013.38

Hart, O. (1995). Firms, contracts and financial structure. Clarendon Press.

Hart, O., Shleifer, A., \& Vishny, R. W. (1997). The proper scope of government: Theory and an application to prisons. Quarterly Journal of Economics, 112(4), 1127-1161.

Hin, S. (2013). The Demography of Roman Italy: Population Dynamics in an Ancient Conquest Society 201 BCE - 14 CE. Cambridge University Press.

Hoffman, P. T. (2017). Public economics and history: A review of fiscal regimes and the political economy of premodern states. Journal of Economic Literature, 55(4), 1556-1569.

Holmstrom, B., \& Milgrom, P. (1991). Multitask principal-agent analyses: Incentive contracts, asset ownership, and job design. Journal of Law, Economics \& Organization, 7, 24-52.

Hopkins, K. (1980). Taxes and trade in the Roman Empire (200 BC-AD 400). The Journal of Roman Studies, 70, 101-125.

Jankowski, R. (2021). The demise of the Roman Republic: A faulty constitution? Constitutional Political Economy, 32, 218-232. https://doi.org/10.1007/s10602-021-09330-0

Jones, A. H. M. (1968). A history of rome through the Fifth Century, The Republic (Vol. 1). Berlin: Springer.

Kiser, E., \& Kane, D. (2007). The perils of privatization: How the characteristics of principals affected tax farming in the Roman Republic and Empire. Social Science History, 31(2), 191-212.

Klein, B., Crawford, R. G., \& Alchian, A. (1978). Vertical integration, appropriable rents, and the competitive contracting process. The Journal of Law \& Economics, 21(2), 297-326.

Kunkel, W. (1952). Herkunft und soziale Stellung der Römischen Juristen. Weimar.

Langlois, R. N. (1995). Do firms plan? Constitutional Political Economy, 6(3), 247-261.

Langlois, R. N., \& Robertson, P. L. (1989). Explaining vertical integration: Lessons from the American automobile industry. Journal of Economic History, 49(2), 361-375.

Levi, M. (1989). Revenue production in Republican Rome (pp. 71-94). University of California Press.

Libman, A., Kozlov, V., \& Schultz, A. (2012). Roving bandits in action: Outside option and governmental predation in autocracies. Kyklos, 65(4), 526-562. 
Lintott, A. (1990). Electoral bribery in the Roman Republic. The Journal of Roman Studies, 80, 1-16.

Macher, J. T., \& Richman, B. D. (2008). Transaction cost economics: An assessment of empirical research in the social sciences. Business and Politics, 10(1), 1-63.

McGuire, M., \& Olson, M. (1996). The economics of autocracy and majority rule. Journal of Economic Literature, 34(1), 72-96.

McLeister, K. (2016). Publicani in the principate (Doctoral dissertation). McMaster University.

Murphy, R. H. (2019). Governance and the dimensions of autocracy. Constitutional Political Economy, 30(2), 131-148.

Neesen, L. (1981). The revenues of Rome. The Journal of Roman Studies, 71, 161-172.

Olson, M. (1991). Autocracy, democracy, and prosperity. Strategy and Choice, 131(157), 131-157.

Olson, M. (1993). Dictatorship, democracy, and development. American Political Science Review, 87(3), 567-576.

Overland, J., Simons, K. L., \& Spagat, M. (2005). Political instability and growth in dictatorships. Public Choice, 125(3-4), 445-470.

Poitras, G., \& Geranio, M. (2016). Trading of shares in the Societates Publicanorum? Explorations in Economic History, 61, 95-118.

Pritchard, R. T. (1971). Gaius Verres and the Sicilian farmers. Historia: Zeitschrift Fur Alte Geschichte, 20(2-3), 224-238.

Rathbone, D. (1993). Egypt, augustus and Roman taxation. Cahiers Du Centre Gustave Glotz, 4, 81-112.

Rathbone, D. (1996). The imperial finances. In A. Bowman, E. Champlin, \& A. Lintott (Eds.), The Cambridge ancient history (Vol. 10, pp. 309-323). Cambridge University Press. https://doi.org/10.1017/ CHOL9780521264303.009

Richardson, J. S. (1994). The administration of the Empire. In J. A. Crook, A. Lintott, \& E. Rawson (Eds.), The Cambridge ancient history, 2nd edition (Vol. 9, pp. 564-598). Cambridge University Press.

Roberts, J. (2007). The modern firm: Organizational design for performance and growth. Oxford University Press.

Temin, P. (2001). A market economy in the early Roman Empire. The Journal of Roman Studies, 91, $169-181$.

Temin, P. (2006). The economy of the early Roman Empire. Journal of Economic Perspectives, 20(1), $133-151$.

Walker, W. O. (1978). Jesus and the tax collectors. Journal of Biblical Literature, 97(2), 221-238.

Whinston, M. D. (2003). On the transaction cost determinants of vertical integration. Journal of Law, Economics \& Organization, 19(1), 1-23.

Williamson, O. E. (1975). Markets and hierarchies: Analysis and antitrust implications: A study in the economics of internal organization. Free Press.

Williamson, O. E. (1979). Transaction-cost economics: The governance of contractual relations. Journal of Law \& Economics, 22(2), 233-261.

Williamson, O. (1985). The economic institutions of capitalism. Free Press.

Williamson, O. (1999). Public and private bureaucracies: A transaction cost economics perspective. Journal of Law, Economics, \& Organization., 15(1), 306-342.

Williamson, O. E. (2000). The new institutional economics: Taking stock, looking ahead. Journal of Economic Literature, 38(3), 595-613.

Wittman, D. (1989). Why democracies produce efficient results. Journal of Political Economy, 97(6), $1395-1424$.

Publisher's Note Springer Nature remains neutral with regard to jurisdictional claims in published maps and institutional affiliations. 